\title{
Immune cell therapy for hepatocellular carcinoma
}

\author{
Eishiro Mizukoshi ${ }^{*}$ and Shuichi Kaneko
}

\begin{abstract}
Given the success of immune checkpoint inhibitors and chimeric antigen receptor (CAR) T cells in clinical settings, the host immune system plays an important role in the recognition and targeting of tumor cells in cancer immunotherapy. As a result, there have been numerous advancements in immune cell therapy using human immune cells. However, recent evidence suggests that one type of immunotherapy alone is not effective for the treatment of cancer, particularly solid tumors. Thus, effective immunotherapy combinations, such as the combination of checkpoint inhibitors and immune cell therapy, are needed. This review focuses on hepatocellular carcinoma among other solid tumors and discusses the current status and future of immune cell therapy in cancer immunotherapy.
\end{abstract}

Keywords: T cell, Dendritic cell, Chimeric antigen receptor, Cytokine-induced killer cell, Natural killer cell, Immunotherapy

\section{Background}

Immunotherapy is considered the fourth pillar of cancer treatment after surgery, chemotherapy, and radiation therapy. Immune cells, antibodies, and checkpoint inhibitors are used in immunotherapy. Unlike conventional methods that target cancer cells, immune cell therapy, such as chimeric antigen receptor (CAR) T cell therapy and checkpoint inhibitors, is novel in that it makes use of the host immune system to treat cancer. As such, immune cell therapy may bring about a paradigm shift in the treatment of cancer.

Among the different immunotherapy strategies, we focused on hepatocellular carcinoma (HCC) to introduce the concept of immune cell therapy.

\section{Characteristics of HCC and immunotherapy}

HCC is a malignant epithelial tumor arising from hepatocytes and is often associated with chronic hepatitis and cirrhosis caused by hepatitis B (HBV) or hepatitis C virus (HCV) infections [1]. Recent reports from developed countries suggested that metabolic disorders, such as diabetes, obesity, and fatty liver disease, are risk factors for HCC, indicating that it will become a public health concern [2].

\footnotetext{
* Correspondence: eishirom@m-kanazawa.jp

Department of Gastroenterology, Graduate School of Medicine, Kanazawa University, Kanazawa City, Ishikawa 920-8641, Japan
}

The incidence of $\mathrm{HCC}$ is high in countries where the risk of HBV and HCV infections is also high. These countries include Japan; Korea; China; Taiwan; countries in Southeast Asia; part of Europe, including Italy and Spain; and countries in sub-Saharan Africa. Collectively, over 700,000 individuals die from HCC annually worldwide [3].

Treatments for HCC include hepatectomy, liver transplant, radiofrequency ablation (RFA), hepatic transarterial chemoembolization (TACE), chemotherapy, and molecular targeted therapy. Clinically, patients often undergo combinations of these treatments; however, these treatments are not effective for advanced forms of HCC [4]. In addition, even if the treatment is successful in eliminating HCC, the risk of recurrence is high because patients often have liver diseases that will eventually lead to the development of liver cancer. Therefore, a novel treatment strategy with different mechanisms from those of conventional treatments is needed to improve the prognosis of HCC. Immunotherapy is one such therapy that functions differently from conventional treatments. Recently, checkpoint inhibitors have been used successfully in cancer treatment; however, they are only effective in $10-40 \%$ of cases, and some cancers are resistant to checkpoint inhibitors $[5,6]$. Indeed, previous studies found that checkpoint inhibitors do not elicit cancer-specific $\mathrm{T}$ cell responses in some patients and that cancer-specific $\mathrm{T}$ cells do not reach tumors

(c) The Author(s). 2019 Open Access This article is distributed under the terms of the Creative Commons Attribution 4.0 International License (http://creativecommons.org/licenses/by/4.0/), which permits unrestricted use, distribution, and 
in some cases [7]. In order to improve the effectiveness of checkpoint inhibitors, immune cell therapy may be an effective approach to induce cancer-specific $T$ cells in patients who are resistant to checkpoint inhibitors. In addition to the need for novel treatments, HCC is a suitable model to study treatment effects on recurrence and long-term prognosis as $\mathrm{HCC}$ is associated with multiple recurrences and eventually leads to death.

\section{Targets for immune cell therapy in HCC}

$\mathrm{T}$ cells are the main component involved in the antitumor immune response. The first step required for the development of T cell-based immune cell therapy is to identify antigens expressed on target tumors. Although HCC is not generally considered an immunogenic tumor, HCC patients who have a high level of lymphocyte infiltration in the tumors have a lower risk of recurrence and a better prognosis [8]. Furthermore, one study found that after RFA, patients with a high ratio of circulating tumor antigen-specific cytotoxic $\mathrm{T}$ lymphocytes (CTLs) in the peripheral blood have a significantly lower risk of recurrence than those with a low ratio of CTLs [9]. These findings suggest that HCC patients develop antitumor immunity that suppresses the progression of the disease. Studies in the past 10-15 years identified tumor-associated antigens (TAAs) in HCC and their respective $\mathrm{T}$ cell epitopes, thus confirming the presence of $\mathrm{T}$ cell-mediated immune response to HCC [10-21]. This also suggests that a novel immunotherapy for HCC can be established by developing a method to elicit potent antitumor responses.

Among the TAAs, the immune response to $\alpha$ fetoprotein (AFP) has been studied in depth since CTL epitopes for AFP were identified at an early stage [10, 22]. AFP is a carcinoembryonic antigen and is produced in the body during fetal development. Although AFP is no longer produced soon after birth, it is produced again in HCC patients. Previous studies demonstrated that HCC patients are more likely to have $\mathrm{T}$ cells specific to AFP epitopes in the peripheral blood than healthy individuals and that the ratio of these $T$ cells in the peripheral blood increases with cancer progression and after RFA and TACE $[9,23]$.

In addition to AFP, several TAAs have been identified for HCC. They include human telomerase reverse transcriptase (hTERT), melanoma antigen gene-A (MAGEA), glypican-3 (GPC3), NY-ESO-1, cyclophyrin-B (Cyp$B)$, squamous cell carcinoma antigen recognized by $\mathrm{T}$ cells (SART), p53, and multidrug resistance-associated protein 3 (MRP3) [11, 12, 15, 16, 20, 21, 24, 25] (Table 1)

\section{Antitumor immune response in HCC patients}

Identification of CTL epitopes has led to the development of cancer immunotherapy. Furthermore, it is essential to understanding the mechanisms underlying immune response in HCC patients. One study examined

Table 1 Cytotoxic T cell epitopes expressed in hepatocellular carcinoma and their T cell receptors

\begin{tabular}{|c|c|c|c|c|c|c|c|c|}
\hline Antigen & $\begin{array}{l}\text { Frequency of } \\
\text { occurrence (\%) }\end{array}$ & $\begin{array}{l}\text { Cytotoxic T } \\
\text { cell epitope }\end{array}$ & $\begin{array}{l}\mathrm{HLA} \\
\text { restriction }\end{array}$ & $\begin{array}{l}\text { Year of } \\
\text { report }\end{array}$ & $\begin{array}{l}\text { Reporter } \\
\text { [reference] }\end{array}$ & $\begin{array}{l}\text { T cell } \\
\text { receptor* }\end{array}$ & $\begin{array}{l}\text { Year of } \\
\text { report }\end{array}$ & $\begin{array}{l}\text { Reporter } \\
\text { [reference] }\end{array}$ \\
\hline \multirow[t]{2}{*}{ AFP } & \multirow[t]{2}{*}{$<80$} & $\mathrm{AFP}_{137}, \mathrm{AFP}_{158}$ & $\mathrm{~A} 2$ & 1999 & Butterfield et al. [10] & $\mathrm{AFP}_{158}$ & 2018 & $\begin{array}{l}\text { Docta et al. } \\
{[26]}\end{array}$ \\
\hline & & $\mathrm{AFP}_{325}, \mathrm{AFP}_{542}, \mathrm{AFP}_{357}, \mathrm{AFP}_{403}$ & $\mathrm{~A} 24$ & 2006 & Mizukoshi et al. [14] & $\mathrm{AFP}_{357}$ & 2017 & $\begin{array}{l}\text { Nakagawa et al. } \\
{[27]}\end{array}$ \\
\hline NY-ESO-1 & $<50$ & NY-ESO- $1_{157}$ & $\mathrm{~A} 2$ & 2004 & Korangy et al. [11] & NY-ESO-1 157 & 2014 & $\begin{array}{l}\text { Robbins et al. } \\
{[28]}\end{array}$ \\
\hline \multirow[t]{2}{*}{ MAGE-A } & \multirow[t]{2}{*}{$<80$} & MAGE-1 161, MAGE-3 271 & $\mathrm{~A} 1, \mathrm{~A} 2$ & 2004 & Zerbini et al. [12] & & & \\
\hline & & MAGE-10 254 & A2 & 2005 & Bricard et al. [13] & & & \\
\hline SSX-2 & $<50$ & $S S X-2_{41}$ & $\mathrm{~A} 2$ & 2005 & Bricard et al. [13] & & & \\
\hline hTERT & $<80$ & $\begin{array}{l}\text { hTERT }_{167}, \text { hTERT }_{324}, \text { hTERT }_{461} \\
\text { hTERT }_{637}, \text { hTERT }_{845}\end{array}$ & A24 & 2006 & Mizukoshi et al. [15] & $\mathrm{hTERT}_{461}$ & 2015 & $\begin{array}{l}\text { Mizukoshi et al. } \\
\text { [29] }\end{array}$ \\
\hline Glypican-3 & $<70$ & $\mathrm{GPC}_{144}, \mathrm{GPC} 3_{298}$ & $\mathrm{~A} 2, \mathrm{~A} 24$ & 2006 & Komori et al. [16] & $\mathrm{GPC}_{367}$ & 2015 & $\begin{array}{l}\text { Dargel et al. } \\
{[30]}\end{array}$ \\
\hline p53 & 100 & $\mathrm{p} 53_{149}, \mathrm{p} 53_{264}$ & $\mathrm{~A} 2$ & 2006 & Cicinnati, et al. [25] & & & \\
\hline HCA661 & Unknown & $\mathrm{HCA}_{66} 61_{110}, \mathrm{HCA} 661_{246}$ & $\mathrm{~A} 2$ & 2007 & Pang et al. [17] & & & \\
\hline MRP3 & $<55$ & $\mathrm{MRP}_{503}, \mathrm{MRP}_{692}, \mathrm{MRP}_{765}$ & A24 & 2008 & Mizukoshi et al. [18] & & & \\
\hline HCA587 & $<70$ & 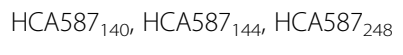 & $A 2$ & 2008 & Xing et al. [19] & & & \\
\hline SART2 & 100 & SART2 93, SART2 161, SART2 899 & A24 & 2012 & Mizukoshi et al. [20] & & & \\
\hline SART3 & 100 & SART3 $_{109}$, SART3 $_{315}$ & $\mathrm{~A} 24$ & 2017 & Kaji et al. [21] & & & \\
\hline
\end{tabular}

AFP alpha-fetoprotein, MAGE melanoma-associated antigen, SSX-2 synovial sarcoma/X breakpoint-2, $h T E R T$ human telomerase reverse transcriptase, $H C A$ hepatocellular carcinoma-associated antigen, SART squamous cell carcinoma antigen recognized by $T$ cell

*The epitopes recognized by cytotoxic $T$ cell receptor were described 
the response of CTLs from HCC patients to several TAA-derived epitopes using enzyme-linked immunospot (ELISPOT) assay. The ratio of TAA-specific CTLs in peripheral mononuclear cells (PBMCs) of HCC patients ranged from 10 to 60.5 cells/300,000 PMBCs, and only 3-19\% of patients had CTLs specific to the epitopes [31]. Immune responses in these ranges are lower than those against virus-derived foreign antigens.

Furthermore, another study examined CTL response using ELISPOT and tetramer assays and identified the presence of non-functional CTLs that bind to antigen epitopes but do not produce cytokines [18]. This demonstrated that as with other types of cancers, host immune response alone is insufficient to eliminate HCC. Thus, there is a need for additional interventions such as immune cell therapy. The following section describes the types of immune cell therapy that have been investigated for the treatment of HCC.

\section{Activated lymphocyte therapy}

Several forms of immune cell therapy have been evaluated for the treatment of cancers. They include immunomodulators, such as OK432; cytokine therapy using interferons (IFN) and interleukins (IL); and lymphokineactivated killer (LAK) and cytokine-induced killer (CIK) cell therapies. Haruta et al. examined two adaptive cell transfer (ACT) techniques for HCC, namely LAK cell therapy and tumor-specific CTL therapy, and demonstrated CTL therapy to be effective as 3 of 18 patients achieved complete response (CR) and 2 of 18 patients achieved partial response (PR) [32]. Moreover, Takayama et al. used LAK cells as an adjuvant to surgery and reported that patients who were administered activated lymphocytes had a 5-year recurrence-free survival rate of $38 \%$ compared with $22 \%$ for those who did not receive the treatment [33].

CIK cell therapy has also been examined in numerous studies as immune cell therapy for HCC based on adaptive cell transfer [34-37]. CIK cells are isolated from PMBCs of patients, grown ex vivo, and cultured with a cytokine cocktail that produces cells with highly potent antitumor activity [36, 38]. Lee et al. found that CIK cell therapy improved the overall survival (OS) of patients when used in combination with either RFA or TACE $[36,37]$. In addition, a phase II non-randomized study demonstrated that the addition of CIK cell therapy to a standard therapy improved OS and progression-free survival (PFS) [35]. These studies suggest that immune cell therapy is effective in reducing the recurrence rate, which is typically high for HCC patients following curative treatment.

\section{Natural killer cell therapy}

Natural killer (NK) cells play an important role in the innate host immune response against viruses and tumors.
The frequency and function of NK cells in the peripheral blood and liver are associated with recurrence and survival rates of patients with resectable HCC [39-41]. Thus, hepatic NK cells are thought to play an important role in mediating the immune function of the liver and immunological defense mechanisms against HCC [42].

Several clinical studies have demonstrated the efficacy of allogenic NK cells in adoptive immunotherapy for solid tumors, including HCC [43-46]. In particular, the combination of percutaneous cryoablation and NK cell therapy was found to be effective in prolonging the PFS of patients with advanced HCC [43]. Furthermore, multiple administration of allogenic NK cells was reported to improve the prognosis of advanced forms of HCC [43] and pancreatic cancer [44].

In addition to these studies, several approaches using genetic modification techniques have been developed to improve the specificity and efficacy of NK cell cytotoxicity to tumor cells. For example, the approach using CAR for $T$ cells (described in a later section) has also been applied to NK cells, improving the specificity and efficacy of NK cell therapy [47-49]. CAR-NK cells reportedly reduce the risks of autoimmune response and neoplastic transformation because they have a shorter lifetime than CAR-T cells. In addition, cytokines released from NK cells, such as IFN- $\gamma$ and granulocyte-macrophage colony-stimulating factor (GM-CSF), are considered safer than the cytokine storm that results from CAR-T cell therapy [50].

Among genetically modified NK cells, GPC3-specific CAR-NK-92 cells were reported to have high antitumor activity against HCC xenografts expressing both low and high levels of GPC3. The specificity of GPC3 CAR-NK-92 cells was confirmed by demonstrating that they are not cytotoxic to GPC3-negative HCC [51]. Clinical trials are currently underway to examine the safety and efficacy of CAR-NK cells [52, 53]. If successful, NK cell therapy may be used clinically for the treatment of solid tumors.

\section{Dendritic cell therapy}

Dendritic cells (DCs) are the most potent antigenpresenting cells in the body. Upon recognition of antigens, DCs are activated and mature to enhance the antitumor immune response via T cells and NK cells $[54,55]$. However, host immune systems involving DCs are restricted in tumors due to several mechanisms, including the low number of DCs in the tumor, reduced ability for antigen presentation, and limited access to tumor antigens [54]. Recent advancements in cell culture techniques revealed that GM-CSF and IL-4 trigger monocytes in the peripheral blood to induce significant activation of DCs. Therefore, artificially induced DCs can be administered intratumorally or subcutaneously to effectively stimulate DC-mediated host immune responses. In addition, current studies are examining the use of toll-like receptor (TLR) 
agonists, TAAs, and TAA-derived peptides as antigens to induce mature DCs that have potent antigen-presenting activity.

In the USA, a DC vaccine called sipuleucel-T was approved by the Food and Drug Administration (FDA) for use in patients with metastatic prostate cancer. Sipuleucel$\mathrm{T}$ is a cell product that was developed by culturing DCs with a tumor antigen (prostatic acid phosphatase (PAP) fusion protein), and has been reported to prolong survival by approximately 4 months in a phase III trial [56].

Numerous DC-based immunotherapy techniques have been examined for HCC [57-65]. Although the majority of these techniques stimulate mature DCs before administration using TAA-derived proteins, TAA-derived peptides, or tumor lysates, DCs can be administered intratumorally without additional stimulation by antigens [57]. Among them, methods using antigen-derived peptides and proteins have the limitation to induce broad immune responses, and therefore, the methods by fusing tumor lysates with dendritic cells have been developed as a tumor vaccine. These techniques may be able to induce antitumor immunity against unknown antigens and their T cell epitopes $[66,67]$. Other techniques have also been examined, including the re-administration of TAA-specific $T$ cells into the body upon stimulation with ex vivo-induced DCs [65], and re-administration of DCs and CIK cells into the body after costimulation [58,60]. Clinical trials and meta-analyses suggested that these DC-based strategies are effective in prolonging PFS and OS [68].

\section{Tumor-infiltrating lymphocyte therapy}

Tumor-infiltrating lymphocyte (TIL) therapy is based on the administration of tumor-specific $\mathrm{T}$ cells, which have been isolated and cultured ex vivo from lymphocytes that have infiltrated resected tumors. Rosenberg et al. infused TILs into patients with advanced malignant melanoma, and 49-72\% of patients achieved either CR or PR [69]. Furthermore, they demonstrated that patients who achieved $C R$ were more likely to survive longer, suggesting that TIL therapy is effective for malignant melanoma. The antitumor effects of TILs may be attributed to TILs containing polyclonal T cells, both $\mathrm{CD}^{+}$and $\mathrm{CD}^{+} \mathrm{T}$ cells, and $\mathrm{T}$ cells that are specific to neoantigens. Overall, the development of TIL therapy confirmed that immunotherapy using cancer-specific $\mathrm{T}$ cells is clinically effective. Although the efficacy of TIL therapy was demonstrated in clinical trials for malignant melanoma, it has not been applied to the treatment of other types of cancers, including HCC, as it is challenging to culture cancerspecific TILs. Gene-modified T cell therapy can overcome these limitations associated with TIL therapy.

\section{Gene-modified T cell therapy}

Gene-modified $\mathrm{T}$ cell therapy has been developed as a method to deliver $\mathrm{T}$ cells that are specific to different types of cancers. It uses $\mathrm{T}$ cells that are genetically engineered to produce $\mathrm{T}$ cell receptors (TCRs) that recognize tumor antigens and their epitopes [70, 71]. Currently, there are two methods of developing gene-modified $\mathrm{T}$ cells: one is based on the use of tumor antigen-specific TCRs from tumor-specific T cells or their clones, and the other is based on the use of CAR (Fig. 1). The extracellular portion of CAR is a single-chain antigen recognition receptor composed of the variable regions of heavy and light chains of a monoclonal antibody specific to the tumor surface antigen, and the intracellular portion of CAR is created by binding of co-stimulatory molecules to the intracellular portion of TCR.

\section{CAR-T cell therapy}

CAR-T cells are T cells modified by viral vectors to express CAR [72-74]. CAR-T cells are not limited by human leukocyte antigen (HLA) because the antigen recognitions site of CAR-T cells consists of monoclonal antibodies that specifically recognize tumor surface antigens.

CD19-CAR-T cell therapy was reported to be effective in a clinical trial as a treatment for recurrent and refractory acute lymphocytic leukemia (ALL) [75]. Similarly, in a trial on 16 patients with refractory ALL, $88 \%$ of the patients achieved CR [76], and in a subsequent trial with 53 patients, $83 \%$ of patients achieved CR by CD19-CAR$\mathrm{T}$ cell therapy [77]. Moreover, in a global, multi-center trial for recurrent and refractory ALL including 75 patients, $81 \%$ achieved remission [78]. CD19-CAR-T cell therapy also led to an approximately $50 \% \mathrm{CR}$ rate in patients with recurrent and refractory $B$ cell nonHodgkin's lymphoma [79, 80]. Thus, CD19-CAR-T cell therapy may be highly effective, and two products have been approved by the FDA and are used clinically.

\section{TCR-engineered $\mathbf{T}$ cell therapy}

TCR-engineered $T$ (TCR-T) cells are produced by modifying $T$ cells with the gene of TCR to specifically recognize the complex of tumor surface antigen peptides and major histocompatibility complex (MHC) molecules. Thus, TCR-T therapy is only effective if tumor cells express target antigen epitopes and MHC molecules. On one hand, HLA restriction needs to be taken into account because there are a variety of human MHC molecules, but all tumor-derived proteins that are processed by proteasomes can be targeted because the antigen itself does not need to be expressed on the cell surface. Therefore, many antigens can be targeted by TCR-T cell therapy. Although there are no commercially available TCR-T cell products, many have been tested in clinical trials (Table 2) [70, 71, 81-90]. Most have been tested against malignant melanoma, but few have been tested against breast cancer, esophageal cancer, or synovial sarcoma. Based on the Response Evaluation Criteria in 


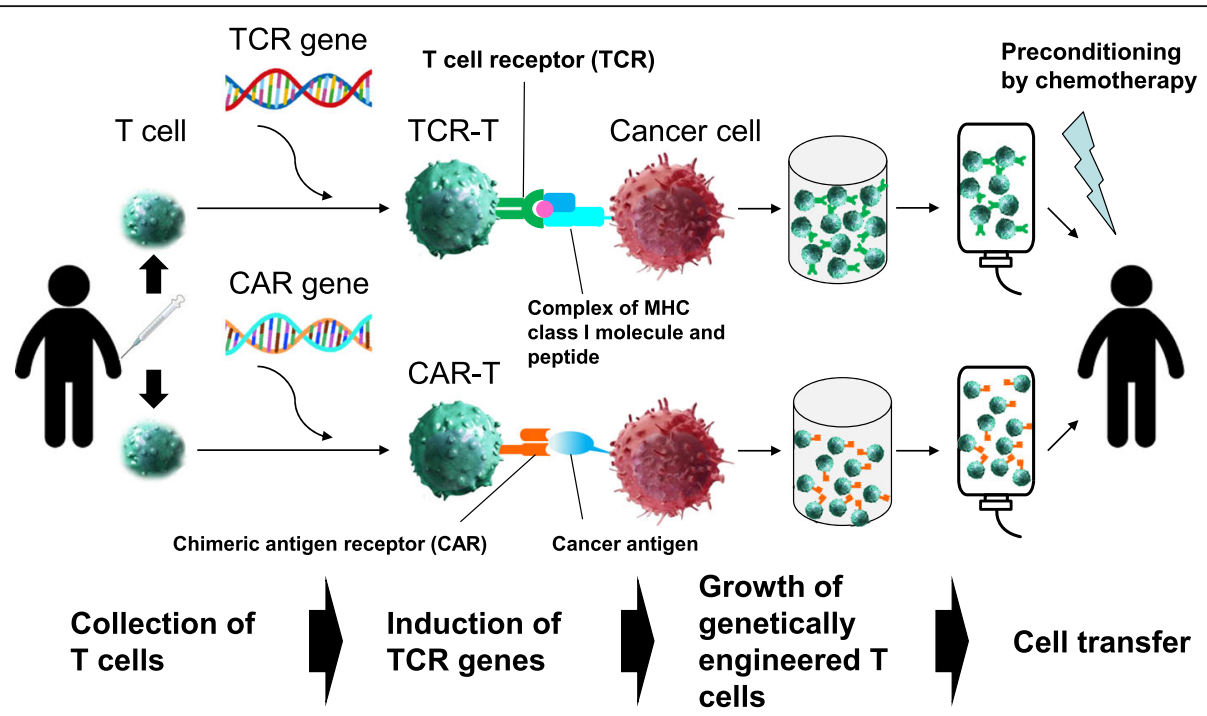

Fig. 1 Overall picture of cancer immunotherapy using gene-modified T cells. This figure shows two methods of developing gene-modified T cells: one is based on the use of tumor antigen-specific TCRs from tumor-specific T cells or their clones which recognize the complex of MHC class I molecule and TAA-derived peptide, and the other is based on the use of CAR

Solid Tumors (RECIST) criteria, patients undergoing TCR-T cell therapy achieved CR and PR.

\section{Harvesting TCRs specific to HCC antigens}

There are several methods to harvest antigen-specific TCRs. One method is to establish a clone of antigen- specific $\mathrm{T}$ cells from tumor-infiltrating lymphocytes or PBMCs of cancer patients and subsequently clone TCRs from these $\mathrm{T}$ cells. However, the process of developing $\mathrm{T}$ cell clones is time-consuming, and the end product is limited to TCRs that originate from $\mathrm{T}$ cells that can be cloned. In other words, even if a TCR has potent

Table 2 Clinical effects and adverse events of T cell receptor gene-modified T cell therapies

\begin{tabular}{|c|c|c|c|c|c|c|}
\hline Antigen & Type of cancer & $\begin{array}{l}\text { Type of T cell } \\
\text { receptor }\end{array}$ & Effects & Adverse events & $\begin{array}{l}\text { Year of } \\
\text { report }\end{array}$ & $\begin{array}{l}\text { Reporter } \\
\text { [reference] }\end{array}$ \\
\hline MART-1 & Malignant melanoma & Wild type & 1/15 PR & Fever, fatigue et al. & 2006 & Duval et al. [81] \\
\hline MART-1 & Malignant melanoma & Wild type & 2/17 PR & Not reported & 2006 & Morgan et al. [70] \\
\hline MART-1 & Malignant melanoma & High affinity & $66 / 20 \mathrm{PR}$ & $\begin{array}{l}\text { Disorders of the skin, eye, } \\
\text { and inner ear }\end{array}$ & 2009 & Johnson et al. [71] \\
\hline MART-1 & Malignant melanoma & $\begin{array}{l}\text { High-affinity } \\
\text { modification }\end{array}$ & $\begin{array}{l}9 / 13 \text { tumor } \\
\text { regression }\end{array}$ & Respiratory failure & 2014 & Chodon et al. [82] \\
\hline gp100 & Malignant melanoma & Mouse origin & $1 / 16 \mathrm{CR}, 2 / 16 \mathrm{PR}$ & Not reported & 2010 & Davis et al. [83] \\
\hline p53 & $\begin{array}{l}\text { Breast cancer, esophageal } \\
\text { cancer, malignant melanoma }\end{array}$ & Mouse origin & 1/10 PR & Not reported & 2010 & Davis et al. [83] \\
\hline CEA & Colon cancer & Mouse origin & 1/3 PR & Colitis & 2011 & Parkhurst et al. [84] \\
\hline \multirow[t]{2}{*}{ NY-ESO-1 } & $\begin{array}{l}\text { Malignant melanoma } \\
\text { Synovial sarcoma }\end{array}$ & \multirow[t]{2}{*}{$\begin{array}{l}\text { High-affinity } \\
\text { modification }\end{array}$} & $\begin{array}{l}\text { 2/11 CR, 3/11 PR, } \\
\text { 4/6PR }\end{array}$ & \multirow[t]{2}{*}{$\begin{array}{l}\text { GVHD, Skin erythema, diarrhea, } \\
\text { decrease in blood pressure }\end{array}$} & 2011 & Robbins et al. [85] \\
\hline & Myeloma & & $14 / 20 \mathrm{CR}, 4 / 20 \mathrm{PR}$ & & 2015 & Rapoport et al. [86] \\
\hline MAGE-A3 & $\begin{array}{l}\text { Malignant melanoma, } \\
\text { myeloma }\end{array}$ & $\begin{array}{l}\text { High-affinity } \\
\text { modification }\end{array}$ & Not evaluated & Cardiogenic shock (death) & 2013 & Cameron et al. [87] \\
\hline MAGE-A4 & Esophageal cancer & Wild type & 3/10 long survival & Not reported & 2015 & $\begin{array}{l}\text { Kageyamama et al. } \\
\text { [88] }\end{array}$ \\
\hline WT-1 & MDS, AML & Wild type & $\begin{array}{l}\text { 2/8 transient blast } \\
\text { loss }\end{array}$ & Not reported & 2017 & Tawara et al. [89] \\
\hline Tyrosinase & Malignant melanoma & Wild type & $1 / 3 P R$ & Vitiligo & 2018 & Moore et al. [90] \\
\hline
\end{tabular}


antitumor activity, it may not be produced using this method if there are few $\mathrm{T}$ cells that express this particular TCR or if T cells expressing the TCR have limited proliferative capacity to establish clones. In order to overcome this limitation, techniques have recently been developed to clone TCRs from a single $\mathrm{T}$ cell $[91,92]$. These techniques enable rapid cloning of TCRs at a single-cell level, resulting in the production of TCRs that cannot be harvested using the conventional method. Using these techniques, cloning of TCRs that bind to HCC-target proteins, including AFP, hTERT, MAGE, and NY-ESO-1, is possible [27-30] (Table 1).

Most TCRs that are isolated from lymphocytes of cancer patients have a low affinity for antigens. Tumor antigens, including differentiation antigens, such as gp100 and MART-1 for malignant melanoma; cancer/testis antigens, such as MAGE3 and NY-ESO-1; and overexpressed antigens, such as carcinoembryonic antigen (CEA) for colon cancer, are self-antigens that are expressed by normal cells. Thus, $\mathrm{T}$ cells harboring TCRs with a low affinity for these antigens typically remain in the body by negative selection in the thymus. Recent studies suggest that genemodified T cell therapy using these low-affinity TCRs has limited antitumor effects. Several techniques have been developed in order to overcome this limitation, including a technique to artificially modify TCRs to make them high-affinity receptors [26] and a technique to immunize HLA transgenic mice using target antigens to isolate mouse-derived high-affinity TCRs [93].

\section{Perspective of gene-modified $\mathrm{T}$ cell therapy for HCC}

We will first discuss preclinical studies on gene-modified $\mathrm{T}$ cell therapy for HCC. These studies used antigens and epitopes from HCV and AFP [93, 94]; TCR genes for $\mathrm{HCV}$ antigens and epitopes were isolated from human $\mathrm{T}$ cells, whereas those for AFP antigens and epitopes were isolated from human and murine T cells. One study examined the effect of TCR-T cell therapy using TCRs that recognize $\mathrm{HCV}$ and AFP-derived epitopes. The study used a super immunodeficient mouse model to grow HepG2 cells expressing the target antigens and demonstrated that TCR-T cell therapy was effective against HepG2 tumors in vivo. Future clinical trials may reveal that the treatment is also clinically effective in humans. Indeed, a phase I clinical trial is underway to examine TCR-T cell therapy that targets AFP in patients with advanced HCC (ClinicalTrials.gov identifier: NCT03132792). Regarding CAR-T cell therapy, one study used GPC-3 as a target in HCC, which prolonged the survival of mice harboring GPC-3 positive hepatic tumors [95].

In addition to GPC-3, mucin 1 (MUC1) and epithelial cell adhesion molecule (EpCAM) are considered to be good targets for CAR-T cell therapy in HCC patients.
CAR-T cells that target these antigens are currently being developed for other cancer types [96, 97]. These CAR-T cells are also being tested for HCC in clinical trials (ClinicalTrials.gov identifier: NCT02587689, NCT03013712, NCT02729493, etc.) [97, 98], and positive outcomes are expected. Discovery of novel HCC-specific surface antigens may lead to the development of CAR-T cell therapy based on antibodies that recognize such antigens.

\section{Side effects of gene-modified T cell therapy}

Many studies to date have described side effects associated with gene-modified $\mathrm{T}$ cell therapy. In CAR-T cell therapy, cytokine release syndrome (CRS) involving IFN- $\gamma$ and interleukin-6 (IL-6) occurs in ALL patients due to enhanced immune cell activation [99-101]. Neurotoxicity is also one of the characteristic and important side effects of CAR-T cell therapy. Recent studies are revealing pathophysiology and risk factors of CRS and neurotoxicity [102]. The onset of these side effects is thought to be deeply involved in the process of antigen recognition and proliferation of CAR-T cells, but in studies using xenogeneic mouse models, monocyte/macrophage also plays a role in the onset of these pathologies [103]. Steroid and the antibody against the IL- 6 receptor (tocilizumab) were effective for the treatment of CRS $[104,105]$. On the other hand, in addition to IL-6, the involvement of IL-1 is the onset of CRS or cause of severe neurotoxicity is being clarified, and treatment with IL-1 blockade using anakinra is expected [102, 103]. Tumor lysis syndrome was also reported as a consequence of rapid and marked lysis of tumor cells. Thus, reduction of tumor size is recommended prior to initiating CAR-T cell therapy [106].

A clinical trial of TCR-T cell therapy for melanomaassociated antigens demonstrated that damage to normal melanocytes leads to the development of dermatitis, uveitis, and hearing impairments. TCR-T cell therapy targeting CEA also targeted CEA on normal intestinal epithelial cells and led to severe colitis [107]. Furthermore, TCR-T cell therapy targeting MAGE-A3 led to life-threatening central nervous system disorders and cardiomyopathy $[108,109]$. In the case of myopathy, there was notable damage to myocardial cells not expressing MAGE-A3, and the damage was a consequence of TCR recognizing epitopes from titin, which is a structural protein of striated muscle. Studies are currently ongoing to address these issues with side effects as there are currently no established methods to accurately predict these adverse events prior to treatment. In most cases, HCC patients have reduced liver function because they often have chronic hepatitis or cirrhosis. Future studies should also focus on strategies to prevent and treat associated side effects in order for gene-modified $\mathrm{T}$ cell therapy to be widely used in the treatment of HCC. 


\section{Immunosuppression and its solution in tumor microenvironment}

In the field of cancer immunotherapeutic research, immunosuppressive mechanisms by cancer cells are becoming clear. Regulatory T cells (Tregs), myeloid-derived suppressor cells (MDSCs), and tumor-associated macrophages (TAMs) are known as cells that suppress host antitumor immunity, and these cells are increased in HCC patients and involved in tumor progression [110-112]. The tumor microenvironment is immunosuppressed by such immunosuppressive cells and cytokines such as TGF- $\beta$, IL-10, IL-6, and VEGF, and the mechanism is diverse.

In the liver, it has been reported that sinusoidal endothelial cells induce immune tolerance against CD8-positive $\mathrm{T}$ cells against TAAs released from cancer cells that have undergone apoptosis [113]. In addition, sinusoidal endothelial cells have been reported to contribute to the immunosuppressive environment in the liver by inducing Tregs or PD-L1 through membrane-bound TGF- $\beta$ [114]. Furthermore, liver stellate cells are present in the liver, and in HCC patients in which the cells are activated, an immunosuppressive environment for the tumor is induced and reported to have a poor prognosis [115]. Activated stellate cells have been reported to induce monocytes to an immunosuppressive phenotype, MDSCs, T cell dysfunction, and apoptosis via PD-L1 expression [116].

Recent findings have reported the methods for improving the immunosuppressive environment in such a tumor microenvironment. Lenvatinib has been reported to enhance the therapeutic effect of immune checkpoint inhibitors by reducing TAMs locally at the tumor and enhancing antitumor immunity via interferon (IFN) signal [117]. In fact, also in human clinical trials, the efficacy of the combination therapy of lenvatinib and pembrolizumab has been reported [118]. Besides, the efficacy of the combination of VEGF inhibitor (bevacizumab) and anti-PD-L1 antibody (atezolizumab) for HCC has been reported [118]. Because VEGF increases TAMs and Tregs and enhances the expression of immune checkpoint molecules including PD1 molecules of CD8positive T cells $[119,120]$, combination therapy of VEGF inhibitors and anti-PD-1 antibodies makes sense. It is expected that multiplex immunotherapy combining such molecular targeted drugs with immunotherapy will be increasingly developed in the future.

\section{Conclusion}

As discussed in this review, studies on antitumor immunity have advanced rapidly in recent years and many of the findings are currently being applied clinically. These advancements will likely have a significant impact on immunotherapy for solid tumors, and future developments of immune cell therapy, particularly gene-modified $\mathrm{T}$ cell therapy, such as CAR-T or TCR-T cell therapies, are highly anticipated for the prevention of recurrence and as novel treatment strategies for HCC. Future studies should focus on the identification of highly immunogenic TAAs and their respective $\mathrm{T}$ cell epitopes, establishment of safer and more effective gene modification techniques for $\mathrm{T}$ cells, and an improved understanding of the mechanisms underlying the suppression of antitumor effects by tumor cells. These studies will lead to the development of novel and multiplex immunotherapy strategies for the future of cancer treatment.

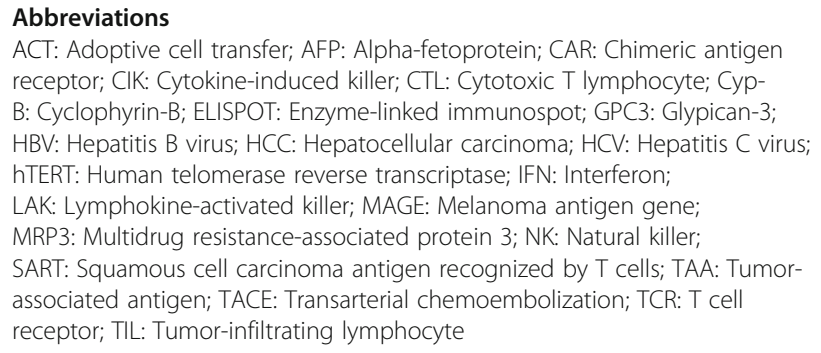

\section{Funding}

The work is partly supported by research grants from the Ministry of Education, Culture, Sports, Science and Technology of Japan (no. 18H02794).

Availability of data and materials

The material supporting the conclusion of this review has been included within the article.

Ethics approval and consent to participate

This is not applicable for this review.

Consent for publication

This is not applicable for this review.

Competing interests

The authors declare that they have no competing interests.

Received: 3 March 2019 Accepted: 10 May 2019

Published online: 29 May 2019

\section{References}

1. Marrero JA, Kulik LM, Sirlin CB, Zhu AX, Finn RS, Abecassis MM, Roberts LR, Heimbach JK. Diagnosis, staging, and management of hepatocellular carcinoma: 2018 practice guidance by the American Association for the Study of Liver Diseases. Hepatology. 2018;68(2):723-50.

2. Makarova-Rusher OV, Altekruse SF, McNeel TS, Ulahannan S, Duffy AG, Graubard Bl, Greten TF, McGlynn KA. Population attributable fractions of risk factors for hepatocellular carcinoma in the United States. Cancer. 2016; 122(11):1757-65.

3. Ferlay J, Soerjomataram I, Dikshit R, Eser S, Mathers C, Rebelo M, Parkin DM, Forman D, Bray F. Cancer incidence and mortality worldwide: sources, methods and major patterns in GLOBOCAN 2012. Int J Cancer. 2015;136(5): E359-86.

4. Heimbach JK, Kulik LM, Finn RS, Sirlin CB, Abecassis MM, Roberts LR, Zhu AX, Murad $\mathrm{MH}$, Marrero JA. AASLD guidelines for the treatment of hepatocellular carcinoma. Hepatology. 2018;67(1):358-80. 
5. Hamid O, Robert C, Daud A, Hodi FS, Hwu WJ, Kefford R, Wolchok JD, Hersey P, Joseph RW, Weber JS, Dronca R, Gangadhar TC, Patnaik A, Zarour H, Joshua AM, Gergich K, Elassaiss-Schaap J, Algazi A, Mateus C, Boasberg P, Tumeh PC, Chmielowski B, Ebbinghaus SW, Li XN, Kang SP, Ribas A. Safety and tumor responses with lambrolizumab (anti-PD-1) in melanoma. N Engl J Med. 2013:369(2):134-44

6. Callahan MK, Postow MA, Wolchok JD. CTLA-4 and PD-1 pathway blockade: combinations in the clinic. Front Oncol. 2014:4:385

7. Sharma P, Allison JP. The future of immune checkpoint therapy. Science. 2015;348(6230):56-61.

8. Wada Y, Nakashima O, Kutami R, Yamamoto O, Kojiro M. Clinicopathological study on hepatocellular carcinoma with lymphocytic infiltration. Hepatology. 1998;27(2):407-14.

9. Mizukoshi E, Yamashita T, Arai K, Sunagozaka H, Ueda T, Arihara F, Kagaya T, Fushimi K, Kaneko S. Enhancement of tumor-associated antigen-specific T cell responses by radiofrequency ablation of hepatocellular carcinoma. Hepatology. 2013;57(4):1448-57.

10. Butterfield LH, Koh A, Meng W, Vollmer CM, Ribas A, Dissette V, Lee E, Glaspy JA, McBride WH, Economou JS. Generation of human T-cell responses to an HLA-A2.1-restricted peptide epitope derived from alphafetoprotein. Cancer Res. 1999;59(13):3134-42.

11. Korangy F, Ormandy LA, Bleck JS, Klempnauer J, Wilkens L, Manns MP, Greten TF. Spontaneous tumor-specific humoral and cellular immune responses to NY-ESO-1 in hepatocellular carcinoma. Clin Cancer Res. 2004;10(13):4332-41.

12. Zerbini A, Pilli M, Soliani P, Ziegler S, Pelosi G, Orlandini A, Cavallo C, Uggeri J, Scandroglio R, Crafa P, Spagnoli GC, Ferrari C, Missale G. Ex vivo characterization of tumor-derived melanoma antigen encoding gene-specific CD8+cells in patients with hepatocellular carcinoma. J Hepatol. 2004;40(1):102-9.

13. Bricard G, Bouzourene H, Martinet O, Rimoldi D, Halkic N, Gillet M, Chaubert P, Macdonald HR, Romero P, Cerottini JC, Speiser DE. Naturally acquired MAGE-A10- and SSX-2-specific CD8+ T cell responses in patients with hepatocellular carcinoma. J Immunol. 2005;174(3):1709-16.

14. Mizukoshi E, Nakamoto Y, Tsuji H, Yamashita T, Kaneko S. Identification of alpha-fetoprotein-derived peptides recognized by cytotoxic $T$ lymphocytes in HLA-A24+ patients with hepatocellular carcinoma. Int J Cancer. 2006; 118(5):1194-204

15. Mizukoshi E, Nakamoto Y, Marukawa Y, Arai K, Yamashita T, Tsuji H, Kuzushima K, Takiguchi M, Kaneko S. Cytotoxic T cell responses to human telomerase reverse transcriptase in patients with hepatocellular carcinoma. Hepatology. 2006;43(6):1284-94.

16. Komori H, Nakatsura T, Senju S, Yoshitake Y, Motomura Y, Ikuta Y, Fukuma D, Yokomine K, Harao M, Beppu T, Matsui M, Torigoe T, Sato N, Baba H, Nishimura Y. Identification of HLA-A2- or HLA-A24-restricted CTL epitopes possibly useful for glypican-3-specific immunotherapy of hepatocellular carcinoma. Clin Cancer Res. 2006;12(9):2689-97.

17. Pang PH, Chan KT, Tse LY, Chan RC, Cheung YK, Sin FW, Guo ZH, Xie Y. Induction of cytotoxic T cell response against HCA661 positive cancer cells through activation with novel HLA-A *0201 restricted epitopes. Cancer Lett. 2007:256(2):178-85.

18. Mizukoshi E, Honda M, Arai K, Yamashita T, Nakamoto Y, Kaneko S. Expression of multidrug resistance-associated protein 3 and cytotoxic T cell responses in patients with hepatocellular carcinoma. J Hepatol. 2008;49(6): 946-54.

19. Xing Q, Pang XW, Peng JR, Yin YH, Li Y, Yu X, Zhou SP, Zhang Y, Chen WF. Identification of new cytotoxic T-lymphocyte epitopes from cancer testis antigen HCA587. Biochem Biophys Res Commun. 2008;372(2):331-5.

20. Mizukoshi E, Fushimi K, Arai K, Yamashita T, Honda M, Kaneko S. Expression of chondroitin-glucuronate (5-epimerase and cellular immune responses in patients with hepatocellular carcinoma. Liver Int. 2012;32(10):1516-26.

21. Kaji K, Mizukoshi E, Yamashita T, Arai K, Sunagozaka H, Fushimi K, Nakagawa H, Yamada K, Terashima T, Kitahara M, Kaneko S. Cellular immune responses for squamous cell carcinoma antigen recognized by T cells 3 in patients with hepatocellular carcinoma. PloS One. 2017;12(1):e0170291.

22. Thimme R, Neagu M, Boettler T, Neumann-Haefelin C, Kersting N, Geissler M, Makowiec F, Obermaier R, Hopt UT, Blum HE, Spangenberg HC. Comprehensive analysis of the alpha-fetoprotein-specific CD8+ T cell responses in patients with hepatocellular carcinoma. Hepatology. 2008;48(6):1821-33.

23. Mizukoshi E, Nakamoto Y, Arai K, Yamashita T, Mukaida N, Matsushima K, Matsui O, Kaneko S. Enhancement of tumor-specific T-cell responses by transcatheter arterial embolization with dendritic cell infusion for hepatocellular carcinoma. Int J Cancer. 2010;126(9):2164-74.
24. Flecken T, Schmidt N, Hild S, Gostick E, Drognitz O, Zeiser R, Schemmer P, Bruns H, Eiermann T, Price DA, Blum HE, Neumann-Haefelin C, Thimme R. Immunodominance and functional alterations of tumor-associated antigenspecific CD8+ T-cell responses in hepatocellular carcinoma. Hepatology. 2014;59(4):1415-26.

25. Cicinnati VR, Zhang X, Yu Z, Ferencik S, Schmitz KJ, Dworacki G, Kaczmarek E, Oldhafer K, Frilling A, Baba HA, Schmid KW, Grosse-Wilde H, Broelsch CE, DeLeo AB, Gerken G, Beckebaum S. Increased frequencies of CD8+ T lymphocytes recognizing wild-type p53-derived epitopes in peripheral blood correlate with presence of epitope loss tumor variants in patients with hepatocellular carcinoma. Int J Cancer. 2006;119(12):2851-60.

26. Docta RY, Ferronha T, Sanderson JP, Weissensteiner T, Pope GD, Bennett AD Pumphrey NJ, Ferjentsik Z, Quinn LL, Wiedermann G, Anderson V, Saini M Maroto M, Norry E, Gerry AB. Tuning T cell receptor affinity to optimize clinical risk-benefit when targeting alpha-fetoprotein-positive liver cancer. Hepatology. 2019;69(5):2061-75.

27. Nakagawa H, Mizukoshi E, Kobayashi E, Tamai T, Hamana H, Ozawa T, Kishi H, Kitahara M, Yamashita T, Arai K, Terashima T, lida N, Fushimi K, Muraguchi A, Kaneko S. Association between high-avidity T-cell receptors, induced by alpha-fetoprotein-derived peptides, and anti-tumor effects in patients with hepatocellular carcinoma. Gastroenterology. 2017;152(6):1395-406 e1310.

28. Robbins PF, Kassim SH, Tran TL, Crystal JS, Morgan RA, Feldman SA, Yang JC, Dudley ME, Wunderlich JR, Sherry RM, Kammula US, Hughes MS, Restifo NP, Raffeld M, Lee CC, Li YF, El-Gamil M, Rosenberg SA. A pilot trial using lymphocytes genetically engineered with an NY-ESO-1-reactive T-cell receptor: long-term follow-up and correlates with response. Clin Cancer Res. 2015;21(5):1019-27.

29. Mizukoshi E, Nakagawa H, Kitahara M, Yamashita T, Arai K, Sunagozaka H, Fushimi K, Kobayashi E, Kishi H, Muraguchi A, Kaneko S. Immunological features of T cells induced by human telomerase reverse transcriptasederived peptides in patients with hepatocellular carcinoma. Cancer Lett. 2015;364(2):98-105.

30. Dargel C, Bassani-Sternberg M, Hasreiter J, Zani F, Bockmann JH, Thiele F, Bohne F, Wisskirchen K, Wilde S, Sprinzl MF, Schendel DJ, Krackhardt AM, Uckert W, Wohlleber D, Schiemann M, Stemmer K, Heikenwalder M, Busch DH, Richter G, Mann M, Protzer U. T cells engineered to express a T-cell receptor specific for glypican-3 to recognize and kill hepatoma cells in vitro and in mice. Gastroenterology. 2015;149(4):1042-52.

31. Mizukoshi E, Nakamoto Y, Arai K, Yamashita T, Sakai A, Sakai Y, Kagaya T, Honda M, Kaneko S. Comparative analysis of various tumor-associated antigen-specific t-cell responses in patients with hepatocellular carcinoma. Hepatology. 2011;53(4):1206-16.

32. Haruta I, Yamauchi K, Aruga A, Komatsu T, Takasaki K, Hayashi N, Hanyu F. Analytical study of the clinical response to two distinct adoptive immunotherapies for advanced hepatocellular carcinoma: comparison between LAK cell and CTL therapy. J Immunother Emphasis Tumor Immunol. 1996;19(3):218-23.

33. Takayama T, Sekine T, Makuuchi M, Yamasaki S, Kosuge T, Yamamoto J, Shimada K, Sakamoto M, Hirohashi S, Ohashi Y, Kakizoe T. Adoptive immunotherapy to lower postsurgical recurrence rates of hepatocellular carcinoma: a randomised trial. Lancet. 2000;356(9232):802-7.

34. Huang ZM, Li W, Li S, Gao F, Zhou QM, Wu FM, He N, Pan CC, Xia JC, Wu $\mathrm{PH}$, Zhao M. Cytokine-induced killer cells in combination with transcatheter arterial chemoembolization and radiofrequency ablation for hepatocellular carcinoma patients. J Immunother. 2013;36(5):287-93.

35. Yu X, Zhao H, Liu L, Cao S, Ren B, Zhang N, An X, Yu J, Li H, Ren X. A randomized phase II study of autologous cytokine-induced killer cells in treatment of hepatocellular carcinoma. J Clin Immunol. 2014;34(2):194-203.

36. Lee JH, Lim YS, Yeon JE, Song TJ, Yu SJ, Gwak GY, Kim KM, Kim YJ, Lee JW, Yoon $J$ H. Adjuvant immunotherapy with autologous cytokine-induced killer cells for hepatocellular carcinoma. Gastroenterology. 2015;148(7):1383-1391 e1386.

37. Lee JH, Lim YS, Yeon JE, Song TJ, Yu SJ, Gwak GY, Kim KM, Kim YJ, Lee JW, Yoon JH. Sustained efficacy of adjuvant immunotherapy with cytokineinduced killer cells for hepatocellular carcinoma: an extended 5-year followup. Cancer Immunol Immunother. 2019;68(1):23-32.

38. Schmidt-Wolf IG, Lefterova P, Mehta BA, Fernandez LP, Huhn D, Blume KG, Weissman IL, Negrin RS. Phenotypic characterization and identification of effector cells involved in tumor cell recognition of cytokine-induced killer cells. Exp Hematol. 1993;21(13):1673-9.

39. Chew V, Chen J, Lee D, Loh E, Lee J, Lim KH, Weber A, Slankamenac K, Poon RT, Yang H, Ooi LL, Toh HC, Heikenwalder M, Ng IO, Nardin A, Abastado JP. 
Chemokine-driven lymphocyte infiltration: an early intratumoural event determining long-term survival in resectable hepatocellular carcinoma. Gut. 2012;61(3):427-38.

40. Cariani E, Pilli M, Zerbini A, Rota C, Olivani A, Zanelli P, Zanetti A, Trenti T, Ferrari C, Missale G. HLA and killer immunoglobulin-like receptor genes as outcome predictors of hepatitis C virus-related hepatocellular carcinoma. Clin Cancer Res. 2013;19(19):5465-73.

41. Sun C, Sun HY, Xiao WH, Zhang C, Tian ZG. Natural killer cell dysfunction in hepatocellular carcinoma and NK cell-based immunotherapy. Acta Pharmacol Sin. 2015;36(10):1191-9.

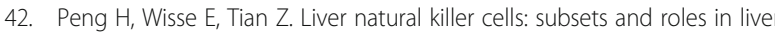
immunity. Cell Mol Immunol. 2016;13(3):328-36.

43. Lin M, Liang S, Wang X, Liang Y, Zhang M, Chen J, Niu L, Xu K. Cryoablation combined with allogenic natural killer cell immunotherapy improves the curative effect in patients with advanced hepatocellular cancer. Oncotarget. 2017:8(47):81967-77.

44. Lin M, Alnaggar M, Liang S, Wang X, Liang $Y$, Zhang M, Chen J, Niu L, Xu K. An important discovery on combination of irreversible electroporation and allogeneic natural killer cell immunotherapy for unresectable pancreatic cancer. Oncotarget. 2017;8(60):101795-807.

45. Lin M, Liang SZ, Wang XH, Liang YQ, Zhang MJ, Niu LZ, Chen JB, Li HB, Xu KC. Clinical efficacy of percutaneous cryoablation combined with allogenic NK cell immunotherapy for advanced non-small cell lung cancer. Immunol Res. 2017;65(4):880-7.

46. Alnaggar M, Lin M, Mesmar A, Liang S, Qaid A, Xu K, Chen J, Niu L, Yin Z. Allogenic natural killer cell immunotherapy combined with irreversible electroporation for stage IV hepatocellular carcinoma: survival outcome. Cell Physiol Biochem. 2018;48(5):1882-93.

47. Romanski A, Uherek C, Bug G, Seifried E, Klingemann H, Wels WS, Ottmann OG, Tonn T. CD19-CAR engineered NK-92 cells are sufficient to overcome NK cell resistance in B-cell malignancies. J Cell Mol Med. 2016;20(7):1287-94.

48. Oelsner S, Friede ME, Zhang C, Wagner J, Badura S, Bader P, Ullrich E, Ottmann OG, Klingemann H, Tonn T, Wels WS. Continuously expanding CAR NK-92 cells display selective cytotoxicity against B-cell leukemia and lymphoma. Cytotherapy. 2017;19(2):235-49.

49. Nowakowska P, Romanski A, Miller N, Odendahl M, Bonig H, Zhang C, Seifried E, Wels WS, Tonn T. Clinical grade manufacturing of genetically modified, CAR-expressing NK-92 cells for the treatment of ErbB2-positive malignancies. Cancer Immunol Immunother. 2018;67(1):25-38.

50. Klingemann $\mathrm{H}$. Are natural killer cells superior CAR drivers? Oncoimmunology. 2014;3:e28147.

51. Yu M, Luo H, Fan M, Wu X, Shi B, Di S, Liu Y, Pan Z, Jiang H, Li Z. Development of GPC3-specific chimeric antigen receptor-engineered natural killer cells for the treatment of hepatocellular carcinoma. Mol Ther. 2018;26(2):366-78.

52. Rezvani K, Rouce R, Liu E, Shpall E. Engineering natural killer cells for cancer immunotherapy. Mol Ther. 2017;25(8):1769-81.

53. Liu E, Tong Y, Dotti G, Shaim H, Savoldo B, Mukherjee M, Orange J, Wan X, Lu X, Reynolds A, Gagea M, Banerjee P, Cai R, Bdaiwi MH, Basar R, Muftuoglu M, Li L, Marin D, Wierda W, Keating M, Champlin R, Shpall E, Rezvani K. Cord blood NK cells engineered to express IL-15 and a CD19targeted CAR show long-term persistence and potent antitumor activity. Leukemia. 2018:32(2):520-31.

54. Shang N, Figini M, Shangguan J, Wang B, Sun C, Pan L, Ma Q, Zhang Z. Dendritic cells based immunotherapy. Am J Cancer Res. 2017:7(10):2091-102.

55. Osada T, Clay T, Hobeika A, Lyerly HK, Morse MA. NK cell activation by dendritic cell vaccine: a mechanism of action for clinical activity. Cancer Immunol Immunother. 2006;55(9):1122-31.

56. Kantoff PW, Higano CS, Shore ND, Berger ER, Small EJ, Penson DF, Redfern CH, Ferrari AC, Dreicer R, Sims RB, Xu Y, Frohlich MW, Schellhammer PF. Sipuleucel-T immunotherapy for castration-resistant prostate cancer. N Engl J Med. 2010;363(5):411-22.

57. Nakamoto $Y$, Mizukoshi E, Kitahara M, Arihara F, Sakai $Y$, Kakinoki K, Fujita $Y$, Marukawa Y, Arai K, Yamashita T, Mukaida N, Matsushima K, Matsui O, Kaneko S. Prolonged recurrence-free survival following OK432-stimulated dendritic cell transfer into hepatocellular carcinoma during transarterial embolization. Clin Exp Immunol. 2011;163(2):165-77.

58. Niu LZ, Li JL, Zeng JY, Mu F, Liao MT, Yao F, Li L, Liu CY, Chen JB, Zuo JS, Xu KC. Combination treatment with comprehensive cryoablation and immunotherapy in metastatic hepatocellular cancer. World J Gastroenterol. 2013;19(22):3473-80
59. El Ansary M, Mogawer S, Elhamid SA, Alwakil S, Aboelkasem F, Sabaawy HE, Abdelhalim O. Immunotherapy by autologous dendritic cell vaccine in patients with advanced HCC. J Cancer Res Clin Oncol. 2013;139(1):39-48.

60. Shimizu K, Kotera Y, Aruga A, Takeshita N, Katagiri S, Ariizumi S, Takahashi Y, Yoshitoshi K, Takasaki K, Yamamoto M. Postoperative dendritic cell vaccine plus activated T-cell transfer improves the survival of patients with invasive hepatocellular carcinoma. Hum Vaccin Immunother. 2014;10(4):970-6.

61. Sun TY, Yan W, Yang CM, Zhang LF, Tang HL, Chen Y, Hu HX, Wei X. Clinical research on dendritic cell vaccines to prevent postoperative recurrence and metastasis of liver cancer. Genet Mol Res. 2015;14(4):16222-32.

62. Yu MA, Liang P, Yu XL, Han ZY, Dong XJ, Wang YU, Cheng C, Li X. Multiple courses of immunotherapy with different immune cell types for patients with hepatocellular carcinoma after microwave ablation. Exp Ther Med. 2015;10(4):1460-6.

63. Lee JH, Lee Y, Lee M, Heo MK, Song JS, Kim KH, Lee H, Yi NJ, Lee KW, Suh KS, Bae YS, Kim YJ. A phase I/lla study of adjuvant immunotherapy with tumour antigen-pulsed dendritic cells in patients with hepatocellular carcinoma. Br J Cancer. 2015;113(12):1666-76.

64. Lee JH, Tak WY, Lee Y, Heo MK, Song JS, Kim HY, Park SY, Bae SH, Heo J, Kim KH, Bae YS, Kim YJ. Adjuvant immunotherapy with autologous dendritic cells for hepatocellular carcinoma, randomized phase II study. Oncoimmunology. 2017;6(7):e1328335.

65. Wang Y, Yang X, Yu Y, Xu Z, Sun Y, Liu H, Cheng J, Liu M, Sha B, Li L, Ding N, Li Z, Jin H, Qian Q. Immunotherapy of patient with hepatocellular carcinoma using cytotoxic T lymphocytes ex vivo activated with tumor antigen-pulsed dendritic cells. J Cancer. 2018;9(2):275-87.

66. Palmer DH, Midgley RS, Mirza N, Torr EE, Ahmed F, Steele JC, Steven NM, Kerr DJ, Young LS, Adams DH. A phase II study of adoptive immunotherapy using dendritic cells pulsed with tumor lysate in patients with hepatocellular carcinoma. Hepatology. 2009;49(1):124-32.

67. Palucka K, Banchereau J. Dendritic-cell-based therapeutic cancer vaccines. Immunity. 2013;39(1):38-48.

68. Chen C, Ma YH, Zhang YT, Zhang F, Zhou N, Wang X, Liu T, Li YM. Effect of dendritic cell-based immunotherapy on hepatocellular carcinoma: a systematic review and meta-analysis. Cytotherapy. 2018;20(8):975-89.

69. Rosenberg SA, Restifo NP. Adoptive cell transfer as personalized immunotherapy for human cancer. Science. 2015;348(6230):62-8.

70. Morgan RA, Dudley ME, Wunderlich JR, Hughes MS, Yang JC, Sherry RM, Royal RE, Topalian SL, Kammula US, Restifo NP, Zheng Z, Nahvi A, de Vries CR, Rogers-Freezer LJ, Mavroukakis SA, Rosenberg SA. Cancer regression in patients after transfer of genetically engineered lymphocytes. Science. 2006; 314(5796):126-9.

71. Johnson LA, Morgan RA, Dudley ME, Cassard L, Yang JC, Hughes MS, Kammula US, Royal RE, Sherry RM, Wunderlich JR, Lee CC, Restifo NP, Schwarz SL, Cogdill AP, Bishop RJ, Kim H, Brewer CC, Rudy SF, VanWaes C, Davis JL, Mathur A, Ripley RT, Nathan DA, Laurencot CM, Rosenberg SA. Gene therapy with human and mouse T-cell receptors mediates cancer regression and targets normal tissues expressing cognate antigen. Blood. 2009;114(3):535-46.

72. Sadelain M, Brentjens R, Riviere I. The basic principles of chimeric antigen receptor design. Cancer Discov. 2013;3(4):388-98.

73. Cheadle EJ, Gornall H, Baldan V, Hanson V, Hawkins RE, Gilham DE. CAR T cells: driving the road from the laboratory to the clinic. Immunol Rev. 2014; 257(1):91-106.

74. Long AH, Haso WM, Shern JF, Wanhainen KM, Murgai M, Ingaramo M, Smith JP, Walker AJ, Kohler ME, Venkateshwara VR, Kaplan RN, Patterson GH, Fry TJ, Orentas RJ, Mackall CL. 4-1BB costimulation ameliorates T cell exhaustion induced by tonic signaling of chimeric antigen receptors. Nat Med. 2015;21(6):581-90.

75. Jackson HJ, Rafiq S, Brentjens RJ. Driving CAR T-cells forward. Nat Rev Clin Oncol. 2016;13(6):370-83.

76. Davila ML, Riviere I, Wang X, Bartido S, Park J, Curran K, Chung SS, Stefanski J, Borquez-Ojeda O, Olszewska M, Qu J, Wasielewska T, He Q, Fink M, Shinglot H, Youssif M, Satter M, Wang Y, Hosey J, Quintanilla H, Halton E, Bernal Y, Bouhassira DC, Arcila ME, Gonen M, Roboz GJ, Maslak P, Douer D, Frattini MG, Giralt S, et al. Efficacy and toxicity management of 19-28z CAR T cell therapy in B cell acute lymphoblastic leukemia. Sci Transl Med. 2014; 6(224):224ra225

77. Park JH, Riviere I, Gonen M, Wang X, Senechal B, Curran KJ, Sauter C, Wang Y, Santomasso B, Mead E, Roshal M, Maslak P, Davila M, Brentjens RJ, Sadelain M. Long-term follow-up of CD19 CAR therapy in acute lymphoblastic leukemia. N Engl J Med. 2018;378(5):449-59. 
78. Maude SL, Laetsch TW, Buechner J, Rives S, Boyer M, Bittencourt H, Bader P, Verneris MR, Stefanski HE, Myers GD, Qayed M, De Moerloose B, Hiramatsu H, Schlis K, Davis KL, Martin PL, Nemecek ER, Yanik GA, Peters C, Baruchel A, Boissel N, Mechinaud F, Balduzzi A, Krueger J, June CH, Levine BL, Wood P, Taran T, Leung M, Mueller KT, et al. Tisagenlecleucel in children and young adults with B-cell lymphoblastic leukemia. N Engl J Med. 2018;378(5):439-48.

79. Neelapu SS, Locke FL, Bartlett NL, Lekakis L, Miklos DB, Jacobson CA, Braunschweig I, Oluwole OO, Siddiqi T, Lin Y, Timmerman JM, Stiff PJ, Friedberg JW, Flinn IW, Goy A, Hill BT, Smith MR, Deol A, Farooq U, McSweeney P, Munoz J, Avivi I, Castro JE, Westin JR, Chavez JC, Ghobadi A, Komanduri KV, Levy R, Jacobsen ED, Witzig TE, et al. Axicabtagene ciloleucel CAR T-cell therapy in refractory large B-cell lymphoma. N Engl J Med. 2017;377(26):2531-44.

80. Schuster SJ, Svoboda J, Chong EA, Nasta SD, Mato AR, Anak O, Brogdon JL, Pruteanu-Malinici I, Bhoj V, Landsburg D, Wasik M, Levine BL, Lacey SF, Melenhorst JJ, Porter DL, June $\mathrm{CH}$. Chimeric antigen receptor T cells in refractory B-cell lymphomas. N Engl J Med. 2017;377(26):2545-54.

81. Duval L, Schmidt H, Kaltoft K, Fode K, Jensen JJ, Sorensen SM, Nishimura MI von der Maase $\mathrm{H}$. Adoptive transfer of allogeneic cytotoxic T lymphocytes equipped with a HLA-A2 restricted MART-1 T-cell receptor: a phase I trial in metastatic melanoma. Clin Cancer Res. 2006;12(4):1229-36.

82. Chodon T, Comin-Anduix B, Chmielowski B, Koya RC, Wu Z, Auerbach M, Ng C, Avramis E, Seja E, Villanueva A, McCannel TA, Ishiyama A, Czernin J, Radu CG, Wang X, Gjertson DW, Cochran AJ, Cornetta K, Wong DJ, Kaplan-Lefko P, Hamid O, Samlowski W, Cohen PA, Daniels GA, Mukherji B, Yang L, Zack JA, Kohn DB, Heath JR, Glaspy JA, et al. Adoptive transfer of MART-1 T-cell receptor transgenic lymphocytes and dendritic cell vaccination in patients with metastatic melanoma. Clin Cancer Res. 2014;20(9):2457-65.

83. Davis $\mathrm{J}$, Theoret MR, Zheng Z, Lamers CH, Rosenberg SA, Morgan RA. Development of human anti-murine T-cell receptor antibodies in both responding and nonresponding patients enrolled in TCR gene therapy trials. Clin Cancer Res. 2010;16(23):5852-61.

84. Parkhurst MR, Yang JC, Langan RC, Dudley ME, Nathan DA, Feldman SA, Davis JL, Morgan RA, Merino MJ, Sherry RM, Hughes MS, Kammula US, Phan GQ, Lim RM, Wank SA, Restifo NP, Robbins PF, Laurencot CM, Rosenberg SA. $T$ cells targeting carcinoembryonic antigen can mediate regression of metastatic colorectal cancer but induce severe transient colitis. Mol Ther. 2011;19(3):620-6.

85. Robbins PF, Morgan RA, Feldman SA, Yang JC, Sherry RM, Dudley ME, Wunderlich JR, Nahvi AV, Helman LJ, Mackall CL, Kammula US, Hughes MS, Restifo NP, Raffeld M, Lee CC, Levy CL, Li YF, El-Gamil M, Schwarz SL, Laurencot C, Rosenberg SA. Tumor regression in patients with metastatic synovial cell sarcoma and melanoma using genetically engineered lymphocytes reactive with NY-ESO-1. J Clin Oncol. 2011;29(7):917-24.

86. Rapoport AP, Stadtmauer EA, Binder-Scholl GK, Goloubeva O, Vogl DT, Lacey SF, Badros AZ, Garfall A, Weiss B, Finklestein J, Kulikovskaya I, Sinha SK, Kronsberg S, Gupta M, Bond S, Melchiori L, Brewer JE, Bennett AD, Gerry AB, Pumphrey NJ, Williams D, Tayton-Martin HK, Ribeiro L, Holdich T, Yanovich S, Hardy N, Yared J, Kerr N, Philip S, Westphal S, et al. NY-ESO-1-specific TCRengineered $T$ cells mediate sustained antigen-specific antitumor effects in myeloma. Nat Med. 2015;21(8):914-21.

87. Cameron BJ, Gerry AB, Dukes J, Harper JV, Kannan V, Bianchi FC, Grand F, Brewer JE, Gupta M, Plesa G, Bossi G, Vuidepot A, Powlesland AS, Legg A, Adams KJ, Bennett AD, Pumphrey NJ, Williams DD, Binder-Scholl G, Kulikovskaya I, Levine BL, Riley JL, Varela-Rohena A, Stadtmauer EA, Rapoport $A P$, Linette GP, June $C H$, Hassan NJ, Kalos M, Jakobsen BK. Identification of a Titin-derived HLA-A1-presented peptide as a cross-reactive target for engineered MAGE A3-directed T cells. Sci Transl Med. 2013;5(197):197ra103.

88. Kageyama S, Ikeda H, Miyahara Y, Imai N, Ishihara M, Saito K, Sugino S, Ueda S, Ishikawa T, Kokura S, Naota H, Ohishi K, Shiraishi T, Inoue N, Tanabe M, Kidokoro T, Yoshioka H, Tomura D, Nukaya I, Mineno J, Takesako K, Katayama N, Shiku H. Adoptive transfer of MAGE-A4 T-cell receptor genetransduced lymphocytes in patients with recurrent esophageal cancer. Clin Cancer Res. 2015;21(10):2268-77.

89. Tawara I, Kageyama S, Miyahara Y, Fujiwara H, Nishida T, Akatsuka Y, Ikeda H, Tanimoto K, Terakura S, Murata M, Inaguma Y, Masuya M, Inoue N, Kidokoro T, Okamoto S, Tomura D, Chono H, Nukaya I, Mineno J, Naoe T, Emi N, Yasukawa M, Katayama N, Shiku H. Safety and persistence of WT1specific T-cell receptor gene-transduced lymphocytes in patients with AML and MDS. Blood. 2017;130(18):1985-94.

90. Moore T, Wagner CR, Scurti GM, Hutchens KA, Godellas C, Clark AL, Kolawole EM, Hellman LM, Singh NK, Huyke FA, Wang SY, Calabrese KM,
Embree HD, Orentas R, Shirai K, Dellacecca E, Garrett-Mayer E, Li M, Eby JM, Stiff PJ, Evavold BD, Baker BM, Le Poole IC, Dropulic B, Clark JI, Nishimura MI. Clinical and immunologic evaluation of three metastatic melanoma patients treated with autologous melanoma-reactive TCR-transduced T cells. Cancer Immunol Immunother. 2018;67(2):311-25.

91. Kobayashi E, Mizukoshi E, Kishi H, Ozawa T, Hamana H, Nagai T, Nakagawa $H$, Jin A, Kaneko S, Muraguchi A. A new cloning and expression system yields and validates TCRs from blood lymphocytes of patients with cancer within 10 days. Nat Med. 2013;19(11):1542-6.

92. Linnemann C, Heemskerk B, Kvistborg P, Kluin RJ, Bolotin DA, Chen X, Bresser K, Nieuwland M, Schotte R, Michels S, Gomez-Eerland R, Jahn L, Hombrink P, Legrand N, Shu CJ, Mamedov IZ, Velds A, Blank CU, Haanen JB, Turchaninova MA, Kerkhoven RM, Spits H, Hadrup SR, Heemskerk MH, Blankenstein T, Chudakov DM, Bendle GM, Schumacher TN. High-throughput identification of antigen-specific TCRs by TCR gene capture. Nat Med. 2013;19(11):1534-41.

93. Zhu W, Peng Y, Wang L, Hong Y, Jiang X, Li Q, Liu H, Huang L, Wu J, Celis E, Merchen T, Kruse E, He Y. Identification of alpha-fetoprotein-specific T-cell receptors for hepatocellular carcinoma immunotherapy. Hepatology. 2018; 68(2):574-89.

94. Spear TT, Callender GG, Roszkowski JJ, Moxley KM, Simms PE, Foley KC, Murray DC, Scurti GM, Li M, Thomas JT, Langerman A, Garrett-Mayer E, Zhang Y, Nishimura MI. TCR gene-modified T cells can efficiently treat established hepatitis C-associated hepatocellular carcinoma tumors. Cancer Immunol Immunother. 2016;65(3):293-304.

95. Gao H, Li K, Tu H, Pan X, Jiang H, Shi B, Kong J, Wang H, Yang S, Gu J, Li Z. Development of $\mathrm{T}$ cells redirected to glypican-3 for the treatment of hepatocellular carcinoma. Clin Cancer Res. 2014;20(24):6418-28.

96. Qin L, Lai Y, Zhao R, Wei X, Weng J, Lai P, Li B, Lin S, Wang S, Wu Q, Liang Q, Li Y, Zhang X, Wu Y, Liu P, Yao Y, Pei D, Du X, Li P. Incorporation of a hinge domain improves the expansion of chimeric antigen receptor $T$ cells. J Hematol Oncol. 2017;10(1):68

97. Deng Z, Wu Y, Ma W, Zhang S, Zhang YQ. Adoptive T-cell therapy of prostate cancer targeting the cancer stem cell antigen EpCAM. BMC Immunol. 2015:16:1.

98. Chen Y, E CY, Gong ZW, Liu S, Wang ZX, Yang YS, Zhang XW. Chimeric antigen receptor-engineered T-cell therapy for liver cancer. Hepatobiliary Pancreat Dis Int. 2018;17(4):301-9.

99. Brentjens R, Yeh R, Bernal Y, Riviere I, Sadelain M. Treatment of chronic lymphocytic leukemia with genetically targeted autologous T cells: case report of an unforeseen adverse event in a phase I clinical trial. Mol Ther. 2010;18(4):666-8.

100. Morgan RA, Yang JC, Kitano M, Dudley ME, Laurencot CM, Rosenberg SA. Case report of a serious adverse event following the administration of $T$ cells transduced with a chimeric antigen receptor recognizing ERBB2. Mol Ther. 2010;18(4):843-51.

101. Maude SL, Frey N, Shaw PA, Aplenc R, Barrett DM, Bunin NJ, Chew A, Gonzalez VE, Zheng Z, Lacey SF, Mahnke YD, Melenhorst JJ, Rheingold SR, Shen A, Teachey DT, Levine BL, June CH, Porter DL, Grupp SA. Chimeric antigen receptor $T$ cells for sustained remissions in leukemia. N Engl J Med. 2014;371(16):1507-17.

102. Liu D, Zhao J. Cytokine release syndrome: grading, modeling, and new therapy. J Hematol Oncol. 2018;11(1):121.

103. Hay KA. Cytokine release syndrome and neurotoxicity after CD19 chimeric antigen receptor-modified (CAR-) T cell therapy. Br J Haematol. 2018;183(3):364-74.

104. Brentjens RJ, Davila ML, Riviere I, Park J, Wang X, Cowell LG, Bartido S, Stefanski J, Taylor C, Olszewska M, Borquez-Ojeda O, Qu J, Wasielewska T, He Q, Bernal Y, Rijo IV, Hedvat C, Kobos R, Curran K, Steinherz P, Jurcic J, Rosenblat T, Maslak P, Frattini M, Sadelain M. CD19-targeted T cells rapidly induce molecular remissions in adults with chemotherapy-refractory acute lymphoblastic leukemia. Sci Transl Med. 2013;5(177):177ra138.

105. Brudno JN, Kochenderfer JN. Toxicities of chimeric antigen receptor T cells: recognition and management. Blood. 2016;127(26):3321-30.

106. Shank BR, Do B, Sevin A, Chen SE, Neelapu SS, Horowitz SB. Chimeric antigen receptor $T$ cells in hematologic malignancies. Pharmacotherapy. 2017;37(3):334-45

107. Park TS, Rosenberg SA, Morgan RA. Treating cancer with genetically engineered T cells. Trends Biotechnol. 2011;29(11):550-7.

108. Morgan RA, Chinnasamy N, Abate-Daga D, Gros A, Robbins PF, Zheng Z, Dudley ME, Feldman SA, Yang JC, Sherry RM, Phan GQ, Hughes MS, Kammula US, Miller AD, Hessman CJ, Stewart AA, Restifo NP, Quezado MM, Alimchandani M, Rosenberg AZ, Nath A, Wang T, Bielekova B, Wuest SC, 
Akula N, McMahon FJ, Wilde S, Mosetter B, Schendel DJ, Laurencot CM, et al. Cancer regression and neurological toxicity following anti-MAGE-A3 TCR gene therapy. J Immunother. 2013;36(2):133-51.

109. Linette GP, Stadtmauer EA, Maus MV, Rapoport AP, Levine BL, Emery L, Litzky L, Bagg A, Carreno BM, Cimino PJ, Binder-Scholl GK, Smethurst DP, Gerry AB, Pumphrey NJ, Bennett AD, Brewer JE, Dukes J, Harper J, TaytonMartin HK, Jakobsen BK, Hassan NJ, Kalos M, June CH. Cardiovascular toxicity and titin cross-reactivity of affinity-enhanced T cells in myeloma and melanoma. Blood. 2013;122(6):863-71.

110. Ormandy LA, Hillemann T, Wedemeyer H, Manns MP, Greten TF, Korangy F. Increased populations of regulatory $T$ cells in peripheral blood of patients with hepatocellular carcinoma. Cancer Res. 2005;65(6):2457-64.

111. Hoechst B, Ormandy LA, Ballmaier M, Lehner F, Kruger C, Manns MP, Greten TF, Korangy F. A new population of myeloid-derived suppressor cells in hepatocellular carcinoma patients induces CD4(+)CD25(+)Foxp3(+) T cells. Gastroenterology. 2008;135(1):234-43.

112. Wan S, Zhao E, Kryczek I, Vatan L, Sadovskaya A, Ludema G, Simeone DM, Zou W, Welling TH. Tumor-associated macrophages produce interleukin 6 and signal via STAT3 to promote expansion of human hepatocellular carcinoma stem cells. Gastroenterology. 2014;147(6):1393-404.

113. Hochst B, Schildberg FA, Bottcher J, Metzger C, Huss S, Turler A, Overhaus M, Knoblich A, Schneider B, Pantelis D, Kurts C, Kalff JC, Knolle P, Diehl L. Liver sinusoidal endothelial cells contribute to CD8 T cell tolerance toward circulating carcinoembryonic antigen in mice. Hepatology. 2012;56(5):1924-33.

114. Carambia A, Freund B, Schwinge D, Heine M, Laschtowitz A, Huber S, Wraith DC, Korn T, Schramm C, Lohse AW, Heeren J, Herkel J. TGF-beta-dependent induction of CD4(+)CD25(+)Foxp3(+) Tregs by liver sinusoidal endothelial cells. J Hepatol. 2014;61(3):594-9.

115. Ji J, Eggert T, Budhu A, Forgues M, Takai A, Dang H, Ye Q, Lee JS, Kim JH, Greten TF, Wang XW. Hepatic stellate cell and monocyte interaction contributes to poor prognosis in hepatocellular carcinoma. Hepatology. 2015;62(2):481-95.

116. Yu MC, Chen CH, Liang X, Wang L, Gandhi CR, Fung JJ, Lu L, Qian S Inhibition of T-cell responses by hepatic stellate cells via B7-H1-mediated Tcell apoptosis in mice. Hepatology. 2004;40(6):1312-21.

117. Kato Y, Tabata K, Kimura T, Yachie-Kinoshita A, Ozawa Y, Yamada K, Ito J, Tachino S, Hori Y, Matsuki M, Matsuoka Y, Ghosh S, Kitano H, Nomoto K, Matsui J, Funahashi Y. Lenvatinib plus anti-PD-1 antibody combination treatment activates CD8+ T cells through reduction of tumor-associated macrophage and activation of the interferon pathway. PloS one. 2019;14(2): e0212513.

118. Kudo M. Targeted and immune therapies for hepatocellular carcinoma: predictions for 2019 and beyond. World J Gastroenterol. 2019;25(7):789-807.

119. Voron T, Colussi O, Marcheteau E, Pernot S, Nizard M, Pointet AL, Latreche S, Bergaya S, Benhamouda N, Tanchot C, Stockmann C, Combe P, Berger A, Zinzindohoue F, Yagita H, Tartour E, Taieb J, Terme M. VEGF-A modulates expression of inhibitory checkpoints on CD8+ T cells in tumors. J Exp Med. 2015;212(2):139-48.

120. Lapeyre-Prost A, Terme M, Pernot S, Pointet AL, Voron T, Tartour E, Taieb J. Immunomodulatory activity of VEGF in cancer. Int Rev Cell Mol Biol. 2017; 330:295-342.

\section{Publisher's Note}

Springer Nature remains neutral with regard to jurisdictional claims in published maps and institutional affiliations.

Ready to submit your research? Choose BMC and benefit from:

- fast, convenient online submission

- thorough peer review by experienced researchers in your field

- rapid publication on acceptance

- support for research data, including large and complex data types

- gold Open Access which fosters wider collaboration and increased citations

- maximum visibility for your research: over $100 \mathrm{M}$ website views per year

At BMC, research is always in progress.

Learn more biomedcentral.com/submissions 